\title{
Subtype Cross-Reactive, Infection-Enhancing Antibody Responses to Influenza A Viruses
}

\author{
MANABU TAMURA, ${ }^{1}$ ROBERT G. WEBSTER, ${ }^{2}$ AND FRANCIS A. ENNIS ${ }^{1 *}$ \\ Division of Infectious Diseases, Department of Medicine, University of Massachusetts Medical Center, \\ Worcester, Massachusetts 01655, ${ }^{1}$ and Division of Virology, St. Jude Children's \\ Research Hospital, Memphis, Tennessee 38101 ${ }^{2}$
}

Received 30 September 1993/Accepted 3 December 1993

\begin{abstract}
Antibody-dependent enhancement of the uptake of influenza $A$ virus by Fc receptor-bearing cells was analyzed by using virus strains of the three human influenza $A$ virus subtypes, A/PR/8/34 (H1N1), A/Japan/305/57 (H2N2), and A/Port Chalmers/1/73 (H3N2). Immune sera obtained from mice following primary infection with an $\mathrm{H} 1 \mathrm{~N} 1, \mathrm{H} 2 \mathrm{~N} 2$, or $\mathrm{H3N} 2$ subtype virus neutralized only virus of the same subtype; however, immune sera augmented the uptake of virus across subtypes. Immune sera from H1N1-infected mice augmented uptake of the homologous (H1N1) and H2N2 viruses. Antisera to the H2N2 virus augmented the uptake of virus of all subtypes (H1N1, H2N2, or H3N2). Antisera to the H3N2 virus augmented the uptake of the homologous (H3N2) and H2N2 viruses. These results show that subtype cross-reactive, nonneutralizing antibodies augment the uptake of influenza $A$ virus strains of different subtypes. Antibodies to neuraminidase may contribute to the enhanced uptake of viruses of a different subtype, because N2-specific monoclonal antibodies augmented the uptake of both A/Japan/305/57 (H2N2) and A/Port Chalmers/1/73 (H3N2) viruses.
\end{abstract}

Virus-specific antibodies have several roles in preventing and controlling virus infections. Antibodies can inhibit viral infection by virus neutralization. Antibodies can bind to virusinfected cells, and infected cells can then be killed by natural killer cells or monocytes/macrophages, which attach via Fc receptors (FcR) to antibodies bound to infected cells; this is referred to as antibody-dependent cell-mediated cytotoxicity. Antibodies bound to virus-infected cells may induce complement activation, and this can result in cell lysis. In addition, antibody bound to virus particles can enhance uptake of virus by FcR-bearing cells, such as antigen-presenting cells (APCs). This phenomenon, which is called antibody-dependent enhancement $(\mathrm{ADE})$ of virus infection, has been described for several viruses, including influenza $A$ virus $(3,6-8,14,15,17$, 23).

Influenza $\mathrm{A}$ viruses undergo significant antigenic variation of their hemagglutinin (HA) and neuraminidase (NA) molecules, the major glycoproteins that are expressed on the viral surface. Two types of antigenic variation occur: antigenic shift and antigenic drift. Antigenic shift is a major antigenic change in the HA or the NA, and three different subtypes (H1N1, $\mathrm{H} 2 \mathrm{~N} 2$, and $\mathrm{H} 3 \mathrm{~N} 2$ ) of human influenza $A$ viruses have been detected. Antigenic drift represents less marked antigenic changes in the HA and the NA that occur within a subtype.

We previously demonstrated by using reassortant viruses that antibodies to the HA and NA glycoprotein spikes of influenza virus enhance uptake of virus by FcR-bearing cells. We also reported that cross-reactive, nonneutralizing antibodies persisted and enhanced virus uptake of strains within the H3 subtype, despite the drift of neutralizing HA epitopes (24). Ochiai et al. also reported that cross-reactive hemagglutination inhibition antibodies enhanced infection of influenza $A$ virus

* Corresponding author. Mailing address: Division of Infectious Diseases and Immunology, Department of Medicine, University of Massachusetts Medical Center, 55 Lake Ave. North, Worcester, MA 01655. Phone: (508) 856-4182. Fax: (508) 856-5981. strains within the $\mathrm{H} 1$ subtype (15). Experiments using monoclonal antibodies (MAbs) specific to the HA of influenza A virus demonstrated that MAbs could be placed into three groups based on their neutralization $(\mathrm{N})$ and infection-enhancing (E) activities: group I $(\mathrm{N}+\mathrm{E}+)$, group II $(\mathrm{N}+\mathrm{E}-)$, and group III $(\mathrm{N} \pm \mathrm{E}+)$. The epitope recognized by each $\mathrm{MAb}$ was identified by using escape mutant viruses which had a single amino acid substitution compared with the parent virus (25). The presence of ADE antibody has recently been demonstrated by using the sera of young children after primary infection with influenza A virus (6). In the experiments described below, we used sera obtained from mice after primary influenza virus infection with A/PR/8/34 (A/PR; H1N1), A/Japan/305/57 (A/Japan; H2N2), or A/Port Chalmers/1/73 (A/PC; $\mathrm{H} 3 \mathrm{~N} 2$ ) and demonstrated the existence of subtype crossreactive antibodies that enhance uptake of virus but do not neutralize virus of a different subtype. Furthermore, we found that NA-specific MAbs obtained by immunizing with H2N2 subtype virus enhanced the uptake of $\mathrm{H} 3 \mathrm{~N} 2$ subtype virus strains. The presence of cross-subtype-reactive antibodies that enhance virus uptake into FcR-bearing cells, but do not neutralize virus, would result in augmented cross-subtypereactive $\mathrm{T}$ - and $\mathrm{B}$-cell responses.

\section{MATERIALS AND METHODS}

Viruses. Influenza A virus strains A/PR (H1N1), A/Japan $(\mathrm{H} 2 \mathrm{~N} 2)$, and $\mathrm{A} / \mathrm{PC}(\mathrm{H} 3 \mathrm{~N} 2)$ were propagated in 9-day-old embryonated chicken eggs. Infected allantoic fluids were harvested on day 3 after infection, clarified by low-speed centrifugation, aliquoted, and stored at $-80^{\circ} \mathrm{C}$ until use.

Cells. The macrophage-like $\mathrm{P} 388 \mathrm{D}_{1}$ cell line (10) was obtained from the American Type Culture Collection and cultured in RPMI 1640 medium (Flow Laboratories, McLean, Va.) supplemented with $10 \%$ heat-inactivated fetal calf serum, penicillin $\mathrm{G}(100 \mathrm{U} / \mathrm{ml})$, streptomycin $(0.1 \mathrm{mg} / \mathrm{ml})$, and $2 \mathrm{mM}$ L-glutamine. When confluent monolayers were obtained, the cells were detached by pipetting and added at $7 \times 10^{5}$ cells per 
chamber to an eight-chambered slide. Madin-Darby canine kidney (MDCK) cells were maintained in Eagle's minimal essential medium containing penicillin $(100 \mathrm{U} / \mathrm{ml})$, streptomycin $(0.1 \mathrm{mg} / \mathrm{ml})$, and $2 \mathrm{mM}$ L-glutamine supplemented with $10 \%$ heated-inactivated fetal calf serum and were used for plaque neutralizing antibody titration.

Immune sera. Male BALB/c mice, purchased from Charles River Breeding Laboratories, Inc. (Stone Ridge, N.Y.), were infected intranasally with 100 PFU of virus under metophen anesthesia. The mice were bled 4 weeks after infection, and the collected sera were pooled and used as immune sera. Sera were inactivated at $56^{\circ} \mathrm{C}$ for $30 \mathrm{~min}$ and stored $-20^{\circ} \mathrm{C}$.

MAbs. The methods used to obtain hybridoma cell lines which produce antibodies to $\mathrm{N} 2$ neuraminidase were described previously (26). Briefly, BALB/c mice were immunized with one intraperitoneal injection of purified intact reassortant virus $\mathrm{X}-7 \mathrm{~F}_{1}(10 \mu \mathrm{g}$ of HA protein), which possesses the hemagglutinin from $\mathrm{A} / \mathrm{NWS} / 33(\mathrm{H} 1 \mathrm{~N} 1)$ and the neuraminidase from $\mathrm{A} / \mathrm{RI} / 5^{+} / 57$ (H2N2) (9). Fusion was done by using the $\mathrm{SP}_{2} / \mathrm{O}$ Ag 14 cell line (22) 1 to 2 months later, after a similar intravenous booster dose of antigen. The hybridomas producing antibodies to $\mathrm{N} 2$ were cloned in soft agar and grown as ascites in BALB/c mice.

ADE assay. The ADE assay was performed as described previously (24). Briefly, P388 $\mathrm{D}_{1}$ cells on eight-chambered Lab-Tek slides were washed with phosphate-buffered saline (PBS) after treatment with $2.5 \mathrm{mg}$ of neuraminidase (Clostridium perfringens type V; Sigma) per $\mathrm{ml}$. Various dilutions of the mouse immune sera and ascites fluids were added to virus, and the mixtures were incubated for $1 \mathrm{~h}$ at $37^{\circ} \mathrm{C}$ before infection of the $\mathrm{P} 388 \mathrm{D}_{1}$ monolayers for $1 \mathrm{~h}$ at a multiplicity of infection of 0.001. After washing, cells were cultured in RPMI 1640 containing $10 \%$ fetal calf serum for $10 \mathrm{~h}$. The cells were then fixed and stained for the presence of influenza virus antigens by immunofluorescence using a MAb (MAb 8251; Chemicom) to nucleoprotein which reacts with all subtypes of influenza $A$ virus (2a) and fluorescein isothiocyanate-conjugated sheep $\mathrm{F}\left(\mathrm{ab}^{\prime}\right)_{2}$ fragment of anti-murine immunoglobulin $\mathrm{G}$ antibody. The number of infected cells was counted in eight microscopic fields ( $160 \times$ objective) in each chamber. The reproducibility of this assay was previously demonstrated (24).

Titration of neutralizing antibody. Neutralizing antibodies were determined in plaque assays in MDCK cells, using six-well tissue culture plates. Serially diluted mouse immune sera or ascites fluids were preincubated with $50 \mathrm{PFU}$ of virus at $37^{\circ} \mathrm{C}$ for $1 \mathrm{~h}$. After aspiration of medium from the well, $0.1 \mathrm{ml}$ of the mixture of virus and antibody was added to each well and incubated at $37^{\circ} \mathrm{C}$ for $1 \mathrm{~h}$ with occasional agitation. Each well then received $3 \mathrm{ml}$ of agar medium containing minimal essential medium, $0.1 \%$ D-glucose, $0.01 \%$ DEAE-dextran, $1 \%$ vitamins, $0.01 \mathrm{mg}$ of trypsin per $\mathrm{ml}$, and $1 \%$ agar. After 2 days of incubation in $5 \% \mathrm{CO}_{2}$ at $37^{\circ} \mathrm{C}, 3 \mathrm{ml}$ of $2 \%$ neutral red in PBS was overlaid onto the agar in each well. Plaques were counted after $10 \mathrm{~h}$ of incubation. The $90 \%$ plaque neutralizing antibody titers were calculated.

ELISA. Influenza A viruses were propagated in the allantoic fluids of embryonated chicken eggs, and concentrated virus was prepared by centrifugation of infected allantoic fluids at $18,000 \mathrm{rpm}$ in a type 19 rotor for $4 \mathrm{~h}$. The pellets were suspended in $5 \mathrm{ml}$ of Hanks medium with $2 \%$ fetal calf serum. Further purification was obtained by centrifugation for $2 \mathrm{~h}$ at $24,000 \mathrm{rpm}$ over a 20 and $65 \%$ sucrose gradient in a Beckman SW28 rotor. The white buffy layer between the sucrose was collected, and viral protein content was determined by the method of Lowry et al. (11). Purified viruses were used as antigen for the enzyme-linked immunosorbent assay (ELISA).

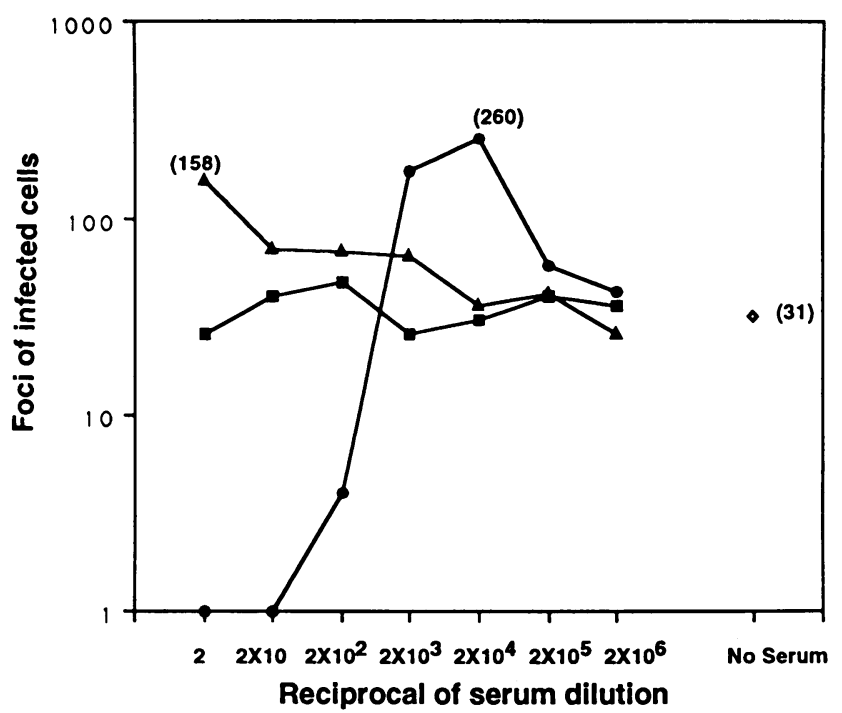

FIG. 1. Effect of dilution of murine polyclonal immune sera (anti$\mathrm{A} / \mathrm{PR}$, anti-A/Japan, and anti-A/PC) on A/PR (H1N1) virus infection of $\mathrm{P} 388 \mathrm{D}_{1}$ cells. $\mathrm{P} 388 \mathrm{D}_{1}$ cells were treated with neuraminidase and infected with $\mathrm{A} / \mathrm{PR}$ virus in the absence of antibody $(\diamond)$ or in the presence of various dilutions of anti-A/PR $(\boldsymbol{\Theta})$, anti-A/Japan $(\boldsymbol{\Delta})$, or anti-A/PC (ם). The number of influenza virus antigen-positive cells was determined by indirect immunofluorescence staining $10 \mathrm{~h}$ after infection. The number of infected cells is shown in parentheses.

Microtiter plates (Dynatech Laboratories, Alexandria, Va.) were coated with purified virus $(1 \mu \mathrm{g}$ per well) in carbonate buffer for $24 \mathrm{~h}$. After being washed with PBS- $0.1 \%$ Tween 20 , the plates were blocked by a 2 -h incubation with $2 \%$ bovine serum albumin in PBS. One hundred microliters of serial threefold dilutions of ascites fluid or serum was added for $2 \mathrm{~h}$ at $37^{\circ} \mathrm{C}$. After washing, $100 \mu \mathrm{l}$ of horseradish peroxidaseconjugated anti-murine immunoglobulin $\mathrm{G}$ antibody was added for $2 \mathrm{~h}$ at $37^{\circ} \mathrm{C}$. Plates were washed, and $100 \mu \mathrm{l}$ of substrate ( $p$-nitrophenyl phosphate) was added. The $A_{405}$ was then determined after $10 \mathrm{~min}$ in a Dynatech MR600 microplate reader. The reciprocal of the dilution of ascites fluid at the midpoint of the exponential part of a semilogarithmic plot of absorbance versus the dilution of ascites fluid was taken as the titer. Titers were expressed as the average of that dilution in duplicate assays.

\section{RESULTS}

ADE of A/PR (H1N1) virus infection. $\mathrm{P}^{388 D_{1}}$ cells were infected with $\mathrm{A} / \mathrm{PR}$ virus alone or after mixing with mouse polyclonal immune sera to A/PR, A/Japan, or A/PC (Fig. 1). The number of foci of A/PR antigen-positive cells was reduced at a serum dilution of $1: 2 \times 10^{2}$ and was enhanced at dilutions from $1: 2 \times 10^{3}$ to $1: 2 \times 10^{4}$ by homologous serum (anti-A/PR serum). Serum from $\mathrm{H} 2 \mathrm{~N} 2$-immunized mice did not neutralize but did enhance uptake by $\mathrm{A} / \mathrm{PR}$ at a dilution of 1:2. Serum from $\mathrm{H} 3 \mathrm{~N} 2$ virus-immune mice did not neutralize or enhance uptake by A/PR. Plaque neutralization titers confirmed these results (Table 1 ).

ADE of A/Japan (H2N2) virus infection. $\mathrm{P}_{388 \mathrm{D}_{1} \text { cells were }}$ infected with $\mathrm{A} / \mathrm{J}$ apan virus alone or after mixing with mouse polyclonal immune sera to A/PR, A/Japan, or A/PC (Fig. 2). The number of foci of $\mathrm{A} / \mathrm{J}$ apan antigen-positive cells was reduced at a serum dilution of $1: 2 \times 10^{2}$ and enhanced at dilutions from $1: 2 \times 10^{3}$ to $1: 2 \times 10^{5}$ by homologous (anti-A/ 
TABLE 1. Neutralization or enhancement of infectious foci of influenza A viruses by convalescent sera

\begin{tabular}{|c|c|c|c|c|c|c|}
\hline \multirow{3}{*}{ Virus } & \multicolumn{6}{|c|}{ Titer of an immune serum against ${ }^{a}$ : } \\
\hline & \multicolumn{2}{|c|}{$\mathrm{A} / \mathrm{PR}$} & \multicolumn{2}{|c|}{ A/Japan } & \multicolumn{2}{|c|}{$\mathrm{A} / \mathrm{PC}$} \\
\hline & $\mathbf{N}$ & E & $\mathrm{N}$ & E & $\mathbf{N}$ & E \\
\hline $\begin{array}{l}\text { A/PR (H1N1) } \\
\text { A/Japan (H2N2) } \\
\text { A/PC (H3N2) }\end{array}$ & $\begin{array}{l}\frac{80}{<2} \\
<2\end{array}$ & $\begin{array}{c}\frac{2 \times 10^{4}}{2} \\
<2\end{array}$ & $\begin{array}{l}<2 \\
\frac{640}{<2}\end{array}$ & $\begin{array}{c}\begin{array}{c}2 \\
2 \times 10^{4}\end{array} \\
2\end{array}$ & $\begin{array}{l}<2 \\
<2 \\
320 \\
\end{array}$ & $\begin{array}{c}<2 \\
20 \\
2 \times 10^{3} \\
\end{array}$ \\
\hline
\end{tabular}

${ }^{a} \mathrm{~N}$, plaque neutralization; E, enhancement. Titers of antibodies to homologous virus are underlined. Titers that are above 1:1,000 are given as $10^{x}$, e.g., $2 \times 10^{4}=1: 20,000$.

Japan) serum. The number of foci of $\mathrm{A} / \mathrm{Japan}$ antigen-positive cells was enhanced at dilutions of 1:2 $\times 10$ and 1:2 $\times 10^{2}$ by anti-H3N2 serum and at dilutions of $1: 2$ and $1: 2 \times 10$ by anti-H1N1 serum but was not reduced. Plaque neutralization titers confirmed these results (Table 1).

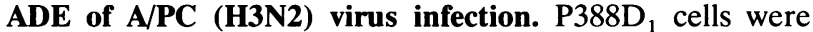
infected with $\mathrm{A} / \mathrm{PC}$ virus alone or after mixing with mouse immune sera to A/PR, A/Japan, or A/PC (Fig. 3). The number of $\mathrm{A} / \mathrm{PC}$ antigen-positive foci was reduced at a serum dilution of $1: 2 \times 10$ and was enhanced at dilutions of $1: 2 \times 10^{3}$ and 1:2 $\times 10^{4}$ by the homologous (anti-A/PC) serum. The number of $\mathrm{A} / \mathrm{PC}$ antigen-positive foci was also enhanced at dilutions from $1: 2$ to $1: 2 \times 10^{2}$ by anti-A/Japan serum but was not reduced. Anti-A/PR serum neither reduced nor enhanced the number of $\mathrm{A} / \mathrm{PC}$ antigen-positive foci. Plaque neutralization titers confirmed these results (Table 1).

Shift of neutralization or enhancement antigens on viruses of different subtypes. Table 1 summarizes the shift of neutralization or enhancement antigens of these three subtypes of

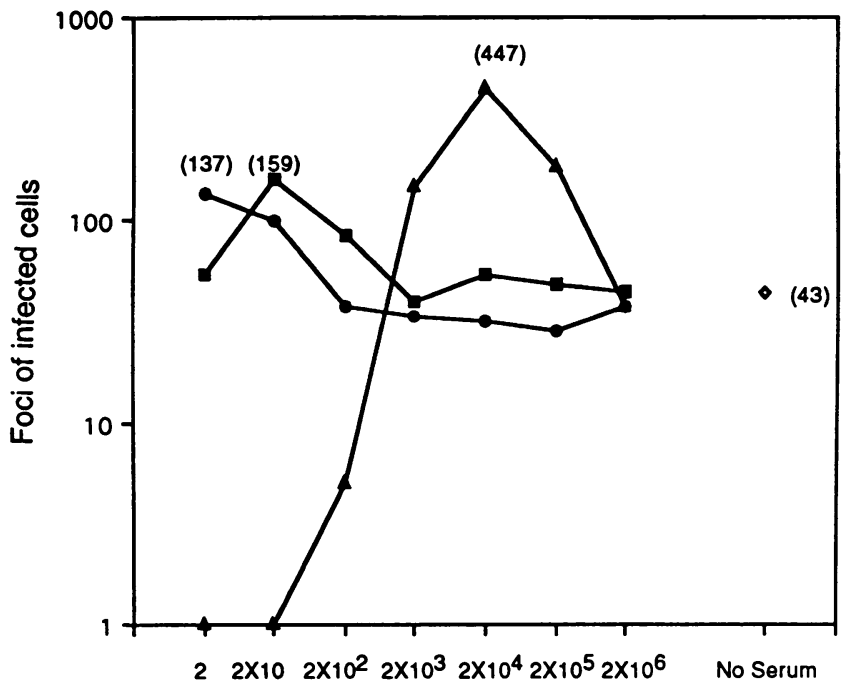

Reciprocal of serum dilution

FIG. 2. Effect of dilution of murine polyclonal immune sera (anti$\mathrm{A} / \mathrm{PR}$, anti-A/Japan, and anti-A/PC) on A/Japan (H2N2) virus infection of $P 388 D_{1}$ cells. $P 388 D_{1}$ cells were treated with neuraminidase and infected with A/Japan virus in the absence of antibody $(\diamond)$ or in the presence of various dilutions of anti-A/PR $(\boldsymbol{O})$, anti-A/Japan $(\boldsymbol{\Delta})$, or anti-A/PC (ם). The number of influenza virus antigen-positive cells was determined by indirect immunofluorescence staining $10 \mathrm{~h}$ after infection. The number of infected cells is shown in parentheses.

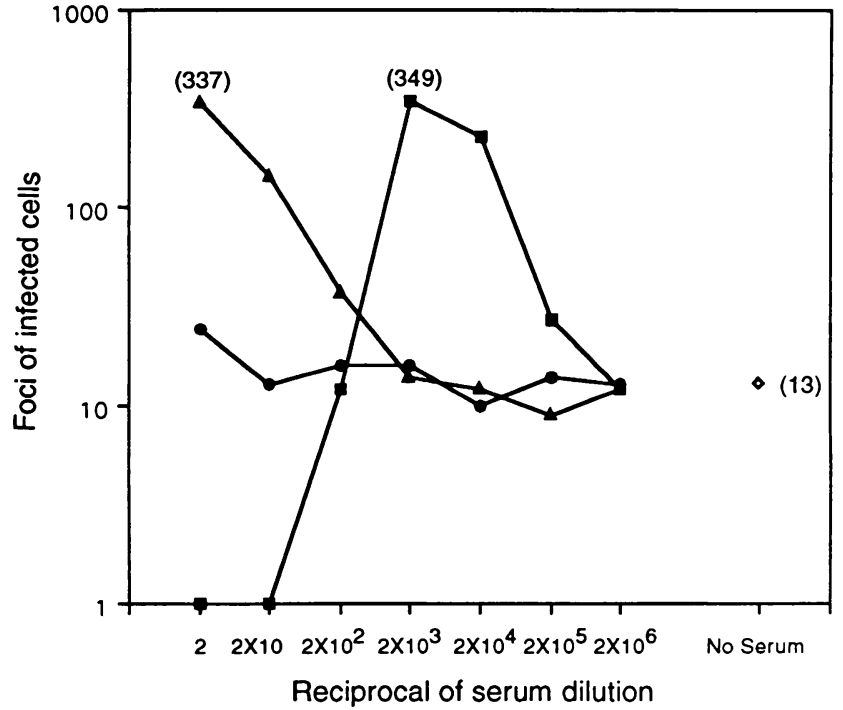

FIG. 3. Effect of dilution of murine polyclonal immune sera (anti$\mathrm{A} / \mathrm{PR}$, anti-A/Japan, and anti-A/PC) on A/PC (H3N2) virus infection of $\mathrm{P} 388 \mathrm{D}_{1}$ cells. $\mathrm{P} 388 \mathrm{D}_{1}$ cells were treated with neuraminidase and infected with A/PC virus in the absence of antibody $(\diamond)$ or in the presence of various dilutions of anti-A/PR $(\boldsymbol{O})$, anti-A/Japan $(\boldsymbol{\Delta})$, or anti-A/PC $(\boldsymbol{\square})$. The number of influenza virus antigen-positive cells was determined by indirect immunofluorescence staining $10 \mathrm{~h}$ after infection. The number of infected cells is shown in parentheses.

human influenza A virus. Immune sera to each subtype virus neutralized the homologous virus but did not neutralize virus of other subtypes. We designated the dilution of serum at which the greatest increase in the number of antigen-positive foci was detected as the enhancement titer.

The enhancement titers of anti-A/PR were $2 \times 10^{4}$ with the anti-A/PR homologous virus (H1N1) and 2 with the H2N2 virus; anti-A/PR did not enhance uptake by the $\mathrm{H} 3 \mathrm{~N} 2$ virus. The enhancement titers of the anti-A/Japan serum were $2 \times$ $10^{4}$ with the homologous virus $(\mathrm{H} 2 \mathrm{~N} 2)$ and 2 with the H1N1 and $\mathrm{H} 3 \mathrm{~N} 2$ viruses. The enhancement titers of the anti-A/PC serum were $2 \times 10^{3}$ with the homologous virus and 20 with the $\mathrm{H} 2 \mathrm{~N} 2$ virus.

An N2 neuraminidase-specific MAb augments uptake of virus infection by both $\mathrm{A} / \mathrm{J}$ apan (H2N2) and $\mathrm{A} / \mathrm{PC}$ (H3N2). We have previously shown by using recombinant viruses that antibodies to HA and NA enhance uptake of influenza A virus (25). The present results demonstrate cross-reactivity of enhancement of virus uptake and the absence of detectable neutralization across subtypes (Table 1 ). Both the $\mathrm{A} / \mathrm{Japan}$ and the $\mathrm{A} / \mathrm{PC}$ viruses contain $\mathrm{N} 2 \mathrm{NA}$; therefore, we analyzed whether an NA-specific MAb could enhance the uptake by viruses of different subtypes. Three MAbs specific to N2 neuraminidase of the $\mathrm{X}-7 \mathrm{~F}_{1}(\mathrm{H} 1 \mathrm{~N} 2)$ virus $(26)$ were analyzed for the ability to reduce or enhance the number of antigen-

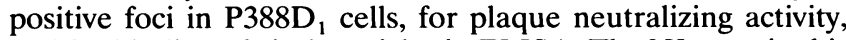
and for binding of viral particles in ELISA. The N2 gene in this $\mathrm{H} 1 \mathrm{~N} 2$ reassortant virus $\left(\mathrm{X}-7 \mathrm{~F}_{1}\right)$ was derived from the $\mathrm{A} / \mathrm{RI} /$ $5^{+} / 57$ (H2N2) virus. MAb 73/1 enhanced the number of antigen-positive foci by the $\mathrm{A} / \mathrm{J}$ apan $(\mathrm{H} 2 \mathrm{~N} 2)$ virus at dilutions from $1: 10$ to $1: 10^{6}$ (Fig. 4A). MAbs $103 / 1$ and $415 / 1$ also enhanced the number of antigen-positive foci at dilutions from $1: 10$ to $1: 10^{4}$ and from $1: 10$ to $1: 10^{2}$, respectively. None of these MAbs reduced the number of antigen-positive foci in $\mathrm{P}_{388 \mathrm{D}_{1}}$ cells. The A/PC (H3N2) virus strain was also analyzed with 

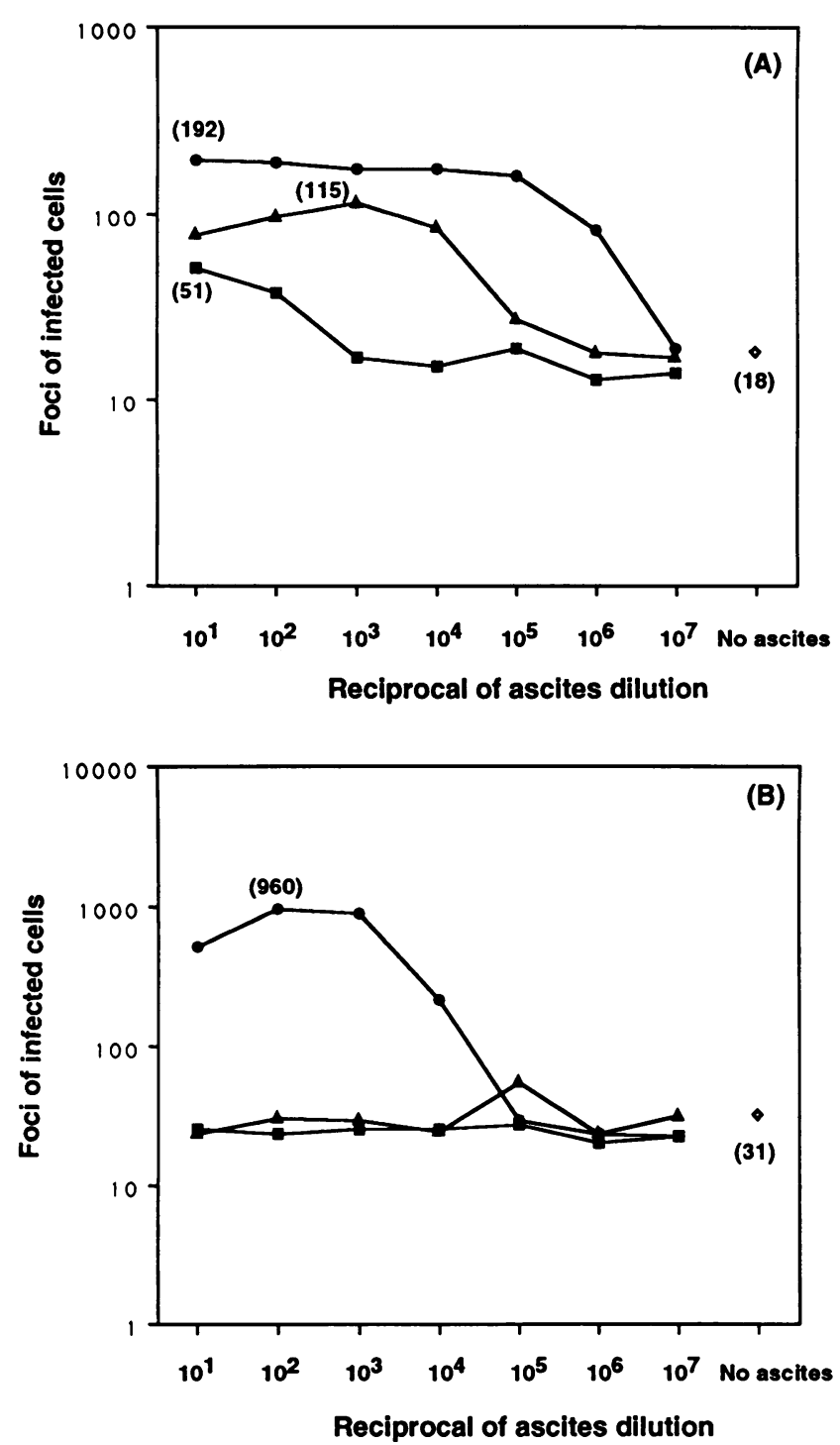

FIG. 4. Effect of dilution of MAbs 73/1, 103/1, and 415/1 on the number of foci of infected $P 388 D_{1}$ cells by $A / J a p a n$ virus $(A)$ and $A / P C$ virus (B). $\mathrm{P}_{388 \mathrm{D}_{1}}$ cells were treated with neuraminidase and infected with $\mathrm{A} / \mathrm{J}$ apan or $\mathrm{A} / \mathrm{PC}$ virus in the absence of antibody $(\diamond)$ or in the presence of various dilutions of MAb 73/1 $(\mathbf{O}), 103 / 1(\Delta)$, or $415 / 1$ (ם). The number of influenza virus antigen-positive cells was determined by indirect immunofluorescence staining $10 \mathrm{~h}$ after infection. The number of infected cells is shown in parentheses. these MAbs. MAb 73/1 enhanced uptake of $\mathrm{A} / \mathrm{PC}$ at dilutions from $1: 10$ to $1: 10^{4}$ but did not reduce the number of antigenpositive foci (Fig. 4B). The other two MAbs (103/1 and 415/1) neither increased nor decreased the number of $\mathrm{A} / \mathrm{PC}$ antigenpositive foci. When MDCK cells were used in plaque neutralization assays, MAb 73/1 neutralized A/Japan virus at a dilution of 160 as reported previously (27), but A/PC virus was not neutralized (Table 2). The other MAbs (103/1 and 415/1) did not neutralize either A/Japan or A/PC. The ELISA titers of $73 / 1$ against $\mathrm{A} / \mathrm{J}$ apan and $\mathrm{A} / \mathrm{PC}$ were $2.4 \times 10^{4}$ and $<100$, respectively. The ELISA titers of the other MAbs (103/1 and $415 / 1$ ) against $\mathrm{A} / \mathrm{J}$ apan and $\mathrm{A} / \mathrm{PC}$ were $<100$.

\section{DISCUSSION}

We previously reported that cross-reactive, nonneutralizing antibodies persist and enhance influenza A virus uptake of FcR-bearing cells, despite the drift of neutralizing antigens of influenza A virus strains within the H3N2 subtype (24). The $\mathrm{HA}$ and NA of influenza virus $\mathrm{A}$ viruses induce antibodies which augment the uptake of influenza A virus by FcR-bearing cells. This was shown by using reassortant viruses which shared only the gene for $\mathrm{HA}$ or NA with virus used to induce antibodies and by using specific antisera to purified HA or NA (24). Those results suggested that enhanced uptake could occur between viruses of different influenza A virus subtypes as a result of cross-reactive antibodies. In these experiments, we demonstrate that cross-reactive, nonneutralizing antibodies are present in immune mouse sera after primary infection and that these antibodies enhance the uptake into FcR-bearing cells of viruses of different subtypes than that used to infect mice. An NA-specific MAb also enhanced uptake across the $\mathrm{H} 2 \mathrm{~N} 2$ and $\mathrm{H} 3 \mathrm{~N} 2$ subtypes.

Anti-A/PR (H1N1) serum neutralized and enhanced the uptake of homologous virus and also enhanced the uptake of the $\mathrm{H} 2 \mathrm{~N} 2$ virus at high concentrations. Anti-A/Japan serum modestly increased the number of antigen-positive foci produced by $\mathrm{A} / \mathrm{PR}, \mathrm{A} / \mathrm{J}$ apan, and $\mathrm{A} / \mathrm{PC}$ viruses but reduced uptake only by the homologous virus. Anti-A/PC serum increased the number of antigen-positive foci produced by $\mathrm{A} / \mathrm{J}$ apan and $\mathrm{A} / \mathrm{PC}$ but reduced uptake only by the homologous virus. There was no convincing cross-subtype-reactive neutralization observed among A/PR (H1N1), A/Japan (H2N2), and A/PC (H3N2); however, cross-reactive enhancement of uptake was detected between the $\mathrm{H} 1 \mathrm{~N} 1$ and $\mathrm{H} 2 \mathrm{~N} 2$ and the $\mathrm{H} 2 \mathrm{~N} 2$ and H3N2 subtypes. Okuno et al. recently described a MAb that recognizes a conserved antigenic site on the $\mathrm{HA}$ of two subtypes (H1N1 and H2N2) of influenza A virus (15a). Such $\mathrm{H} 1$ and $\mathrm{H} 2$ cross-reactive antibodies may be contained in the anti-A/PR and anti-A/Japan sera that we used and enhance uptake by virus of a different subtype at high concentrations of antibody (Fig. 1 and 2). The overall amino acid sequence homology between the N1 and N2 proteins is $40 \%$ (5), and it is possible that antibodies to NA also contribute to the

TABLE 2. Plaque neutralization, focus reduction or enhancement, and ELISA titers of N2 neuraminidase-specific MAbs

\begin{tabular}{|c|c|c|c|c|c|c|c|c|c|c|c|c|}
\hline \multirow{3}{*}{ Virus } & \multicolumn{12}{|c|}{ Titer $^{a}$} \\
\hline & \multicolumn{4}{|c|}{ MAb 73/1 } & \multicolumn{4}{|c|}{ MAb $103 / 1$} & \multicolumn{4}{|c|}{ MAb 415/1 } \\
\hline & $\mathrm{N}$ & $\mathbf{R}$ & E & ELISA & $\mathrm{N}$ & $R$ & $\mathrm{E}$ & $\overline{\text { ELISA }}$ & $\mathrm{N}$ & $\mathbf{R}$ & $\mathrm{E}$ & $\overline{\text { ELISA }}$ \\
\hline $\begin{array}{l}\text { A/Japan (H2N2) } \\
\text { A/PC (H3N2) }\end{array}$ & $\begin{array}{l}160 \\
<10\end{array}$ & $\begin{array}{l}<10 \\
<10\end{array}$ & $\begin{array}{l}10^{5} \\
10^{3}\end{array}$ & $\begin{array}{c}2.4 \times 10^{4} \\
<100\end{array}$ & $\begin{array}{l}<10 \\
<10\end{array}$ & $\begin{array}{l}<10 \\
<10\end{array}$ & $\begin{array}{r}10^{3} \\
<10\end{array}$ & $\begin{array}{l}<100 \\
<100\end{array}$ & $\begin{array}{l}<10 \\
<10\end{array}$ & $\begin{array}{l}<10 \\
<10\end{array}$ & $\begin{array}{r}10 \\
<10\end{array}$ & $\begin{array}{l}<100 \\
<100\end{array}$ \\
\hline
\end{tabular}

${ }^{a} \mathrm{~N}$, plaque neutralization; $\mathrm{R}$, reduction; $\mathrm{E}$, enhancement. 
cross-reactive enhancement of uptake of $\mathrm{H} 1 \mathrm{~N} 1$ and $\mathrm{H} 2 \mathrm{~N} 2$ viruses; however, three NA-specific MAbs to N2 (73/1, 103/1, and 415/1) neither neutralized nor enhanced the uptake of A/PR (data not presented). Since A/Japan and A/PC viruses share the $\mathrm{N} 2$ neuraminidase, we thought that neuraminidasespecific antibodies might be contributing to this cross-subtypereactive increase in the number of antigen-positive foci. We analyzed the ADE activity of three MAbs which are specific to $\mathrm{N} 2$ neuraminidase. These MAbs were obtained by immunizing mice with $\mathrm{X}-7 \mathrm{~F}_{1}(\mathrm{H} 1 \mathrm{~N} 2)$, which contains the $\mathrm{A} / \mathrm{RI} / 5^{+} / 57$ neuraminidase similar to the $\mathrm{N} 2$ neuraminidase of $\mathrm{A} / \mathrm{J}$ apan. All of the three NA-specific MAbs enhanced uptake by the $\mathrm{A} / \mathrm{J}$ apan virus, and MAb 73/1 also enhanced uptake by the $\mathrm{A} / \mathrm{PC}$ virus. None of the three MAbs reduced the number of antigen-positive foci by $\mathrm{A} / \mathrm{J}$ apan and $\mathrm{A} / \mathrm{PC}$ in $\mathrm{P} 388 \mathrm{D}_{1}$ cells; however, MAb 73/1 had some neutralizing antibody on $\mathrm{A} / \mathrm{Ja}-$ pan in MDCK cells, as shown previously (26). Since P388D, cells have FcR, virus uptake via FcR can be augmented in the presence of antibody, and this can mask the neutralizing activity. Thus, the effect of the ADE on uptake may contribute to the differences observed in neutralizing activity in MDCK cells and the number of infectious foci in P388D 1 cells. The enhancement assay seems to be more sensitive than the ELISA, because ELISA titers were lower than enhancement titers (Table 2).

The function of NA in influenza virus infection is still unclear; however, one function of the NA is to remove sialic acid from the carbohydrate moiety of mucin, and this may facilitate virus release from the infected cells (27). Generally, polyclonal antibodies to NA do not neutralize infectivity but do cause plaque size reduction; however, some MAbs to NA have been reported to neutralize virus infection $(26,27)$. Antibody to NA reduced the pathology or mortality caused by influenza virus infection in mice or chickens $(2,19,21)$. With emergence of the H3 subtype in 1968 to 1969 , the population had no immunity to the $\mathrm{H} 3 \mathrm{HA}$ during the $\mathrm{H} 3 \mathrm{~N} 2$ epidemic but had antibodies to the N2 because of previous infections with $\mathrm{H} 2 \mathrm{~N} 2$ viruses. Monto and Kendal reported that the frequency of infection, which was determined serologically by hemagglutinin inhibition in persons with high levels of preexisting naturally acquired antibody to $\mathrm{N} 2 \mathrm{NA}$, was about one-half that of persons without antibody to N2 NA (13). They concluded that antibody against the NA of the influenza virus prevented or modified infection when there was no preexisting anti-H3 HA antibody. We speculate that antibody to NA might also have increased the number of antigen-positive APCs, thereby augmenting activation of influenza A virus-specific $\mathrm{T}$ cells. It is interesting that MAb 73/1 neutralized only $\mathrm{A} / \mathrm{J}$ apan but enhanced the uptake by both $\mathrm{A} / \mathrm{J}$ apan and $\mathrm{A} / \mathrm{PC}$. We have previously demonstrated that enhancing activity persisted after neutralizing activity was lost, using several strains of virus within $\mathrm{H} 3$ subtype (24). We also analyzed MAbs specific to HA of influenza A virus and demonstrated that those MAbs could be divided into three groups based on their $\mathrm{N}$ and $\mathrm{E}$ activities: group I $(\mathrm{N}+\mathrm{E}+)$, group II $(\mathrm{N}+\mathrm{E}-)$, and group III $(\mathrm{N} \pm \mathrm{E}+)$. The epitope for each MAb was identified by using escape mutant viruses which had a single amino acid substitution compared with the parent virus (25). MAb 73/1 recognizes region 2 of NA molecule, which is thought to encompass most of the top surface of the molecule (26). Further analysis will be required to better define the epitope on NA recognized by MAb 73/1.

FcR-bearing cells such as macrophages and B cells are APCs for $\mathrm{T}$ lymphocytes $(1,18)$. It was reported that $\mathrm{T}$-cell responses were enhanced when FcR-bearing APCs were sensitized with antigen in the presence of antibody $(4,12,20)$. Macrophages are not permissive for influenza A virus infection, but viral peptides are presented to T cells on the APC surface in association with major histocompatibility complex molecules. Cross-reactive, nonneutralizing antibodies to HA and NA bind to virus strains of other subtypes. This will result in an increase in the number of antigen-positive APCs and augmented activation of influenza virus-specific $\mathrm{T}$ cells.

\section{REFERENCES}

1. Abbas, A. K., A. H. Lichtman, and J. S. Pober. 1991. Antigen presentation and $\mathrm{T}$ cell antigen recognition, p. 115-137. In M. J. Wonsiewicz (ed.), Cellular and molecular immunology-1991. The W. B. Saunders Co., Philadelphia.

2. Allan, W. H., C. R. Madeley, and A. P. Kendal. 1971. Studies with avian influenza $\mathrm{A}$ viruses: cross protection experiments in chickens. J. Gen. Virol. 12:79-84.

2a.Birmingham, D. Personal communication.

3. Burstin, S. J., M. W. Brandriss, and J. J. Schlesinger. 1983. Infection of a macrophage-like cell line, $\mathrm{P}_{388 \mathrm{D}_{1}}$ with reovirus; effects of immune ascitic fluids and monoclonal antibodies on neutralization and on enhancement of viral growth. J. Immunol. 130:2915-2919.

4. Celis, E., and T. W. Chang. 1984. Antibodies to hepatitis B surface antigen potentiate the response of human $\mathrm{T}$ lymphocyte clones to the same antigen. Science 224:297-299.

5. Colman, P. M., and C. W. Ward. 1985 . Structure and diversity of influenza virus neuraminidase. Curr. Top. Microbiol. Immunol. 114:177-255.

6. Gotoff, R., M. Tamura, J. Janus, J. Thompson, P. Wright, and F. A. Ennis. 1994. Primary influenza A virus infection induces cross-reactive antibodies that enhance uptake of virus into $\mathrm{Fc}$ receptor/bearing cells. J. Infect. Dis. 169:200-203.

7. Halstead, S. B., and E. J. O'Rourke. 1977. Antibody-enhanced dengue virus infection in primate leukocytes. Nature (London) 265:739-741.

8. Homsy, J., M. Tatero, and J. A. Levy. 1988. Antibody-dependent enhancement of HIV infection. Lancet $\mathbf{i}: 1285-1286$.

9. Kilbourne, E. D., W. G. Laver, J. L. Schulman, and R. G. Webster. 1968. Antiviral activity of antiserum specific for an influenza virus neuraminidase. J. Virol. 2:281-288.

10. Koren, H. S., B. S. Handwerger, and J. R. Wunderlich. 1975. Identification of macrophage-like characteristics in a cultured murine tumor line. J. Immunol. 114:894-897.

11. Lowry, O. H., N. J. Rosebrough, A. L. Farr, and R. J. Randall. 1951. Protein measurement with the Folin phenol reagent. J. Biol. Chem. 193:265-275.

12. Manca, F., D. Fenoglio, G. Li Pira, A. Kunkl, and F. Celada. 1991. Effect of antigen/antibody ratio on macrophage uptake, processing, and presentation to $T$ cells of antigen complexed with polyclonal antibodies. J. Exp. Med. 173:37-48.

13. Monto, A. S., and A. P. Kendal. 1973. Effect of neuraminidase antibody on Hong Kong influenza. Lancet i:623-625.

14. Ochiai, H., M. Kurokawa, K. Hayashi, and S. Niwayama. 1988. Antibody-mediated growth of influenza A NWS virus in macro-

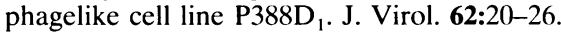

15. Ochiai, H., M. Kurokawa, Y. Kuroki, and S. Niwayama. 1990. Infection enhancement of influenza A H1 subtype viruses in macrophage-like P388D1 cells by cross-reactive antibodies. J. Med. Virol. 30:258-265.

15a.Okuno, Y., Y. Isegawa, F. Sasao, and S. Ueda. 1993. A common neutralizing epitope conserved between the hemagglutinins of influenza $\mathrm{A}$ virus $\mathrm{H} 1$ and $\mathrm{H} 2$ strains. J. Virol. 67:2552-2558.

16. Palese, P., K. Tobita, and M. Ueda. 1974. Characterization of temperature sensitive influenza virus mutants defective in neuraminidase. Virology 61:397-410.

17. Peiris, J. S. M., and J. S. Porterfield. 1979. Antibody-mediated enhancement of flavivirus replication in macrophage-like cell lines. Nature (London) 282:509-511.

18. Ravetch, J. V., and C. L. Anderson. 1990. FcR family: proteins, transcripts and genes, p. 211-235. In H. Metzger (ed.), Fc receptors and the action of antibodies. American Society for Microbiology, Washington, D.C. 
19. Rott, R., H. Becht, and M. Orlich. 1974. The significance of influenza virus neuraminidase in immunity. J. Gen. Virol. 22:3541.

20. Schalke, B. C. G., W. E. F. Klinkert, H. Wekerle, and D. S. Dwyer. 1985. Enhanced activation of a T cell line specific for acetylcholine receptor $(\mathrm{AChR})$ by using anti-AChR monoclonal antibodies plus receptors. J. Immunol. 134:3643-3648.

21. Schulman, J. L., M. Khakpour, and E. D. Kilbourne. 1968 Protective effects of specific immunity to viral neuraminidase on influenza virus infection of mice. J. Virol. 2:778-786.

22. Shulman, M., C. D. Wilde, and G. Kohler. 1978. A better cell line for making hybridomas secreting specific antibodies. Nature (London) 276:269-270.

23. Takeda, A., C. U. Tuazon, and F. A. Ennis. 1988. Antibodyenhanced infection by HIV-1 via Fc receptor-mediated entry.
Science 242:580-583.

24. Tamura, M., R. G. Webster, and F. A. Ennis. 1991. Antibodies to HA and NA augment uptake of influenza A viruses into cells via Fc receptor entry. Virology 182:211-219.

25. Tamura, M., R. G. Webster, and F. A. Ennis. 1993. Neutralization and infection-enhancement epitopes of influenza A virus hemagglutinin. J. Immunol. 151:1731-1738.

26. Webster, R. G., L. E. Brown, and W. G. Laver. 1984. Antigenic and biological characterization of influenza virus neuraminidase (N2) with monoclonal antibodies. Virology 135:30-42.

27. Webster, R. G., V. S. Hinshaw, and W. G. Laver. 1982. Selection and analysis of antigenic variants of the neuraminidase of N2 influenza viruses with monoclonal antibodies. Virology 117:93104. 